\title{
An escaped herd of Iberian wild goat (Capra pyrenaica, Schinz 1838, Bovidae) begins the re-colonization of the Pyrenees
}

\begin{abstract}
In January 2000, the last Pyrenean wild goat, Capra pyrenaica pyrenaica, died in Ordesa National Park in the Spanish Pyrenees. Since that time, there has been an intense debate over the possibility of using individuals from other extant subspecies to restore the Iberian wild goat C. pyrenaica in the Pyrenees. In the late 1990s, some Iberian wild goats of the hispanica subspecies escaped from an enclosure in Guara Nature Park, also in the Spanish Pyrenees. Between 2006 and 2012, four annual counts were conducted to quantify the demographics of the population. This expanding but isolated population numbered at least 86 free-living Iberian wild goats in 2012, reproducing in the wild with a positive increasing trend $(\lambda=1.067)$. Given the small number of original animals that escaped, new releases are necessary to insure the genetic variability of the small population, but only if a clear decision on its conservation is finally made. In addition, the population is sympatric with a population of several hundred feral goats, $C$. hircus, which should be monitored closely, in order to detect any problems with competence or hybridization, although the latter has not been demonstrated in the wild.
\end{abstract}

Keywords: enclosure; feral goats; Guara Nature Park; mountain ungulate; rangers; reintroduction.

\footnotetext{
*Corresponding author: Juan Herrero, Area of Ecology, Technical School of Huesca, University of Zaragoza, E-22071 Huesca, Spain, e-mail: herreroj@unizar.es

Olatz Fernández-Arberas and Ricardo García-González: Pyrenean Institute for Ecology, P.O. Box 64, E-22700 Jaca, Spain

Carlos Prada and Alicia García-Serrano: Ega Wildlife Consultants, Sierra de Vicort, $31,1^{\circ}$ A. E-50003 Zaragoza, Spain
}

\section{Introduction}

Historically, the Pyrenean wild goat Capra pyrenaica pyrenaica Schinz 1838, occupied both sides of the Pyrenees
(Astre 1952, García-González et al. 1996). However, in 2000, the subspecies became extinct when a falling fir Abies alba killed the last female in Ordesa and Monte Perdido National Park (ONP) (Fernández de Luco et al. 2000). The extinction came as a result of a long period of persecution and habitat loss that occurred over several centuries (García-González and Herrero 1999). Currently, there are two extant subspecies of the Iberian wild goat, namely, $C$. pyrenaica: C. p. hispanica (Schimper 1848), which occupies the south and eastern regions of the Iberian Peninsula, and C. p. victoriae (Cabrera 1911), which occurs in the central and northwestern regions of the peninsula (Pérez et al. 2002). Other authors call $C$. pyrenaica Iberian or Spanish ibex (Moço et al. 2006), which we consider incorrect, as other authors have done (Schaller 1977, Pidancier et al. 2006). Thus, in this work, we use the term Iberian wild goat. After one century of absence, $C$. pyrenaica recently re-colonized northern Portugal after animals belonging to the victoriae subspecies escaped from an enclosure (Moço et al. 2006). In recent decades, populations have expanded throughout the Iberian Peninsula (Pérez et al. 2002). C. pyrenaica is considered a species of Least Concern by the International Union for Conservation of Nature (IUCN) (Herrero and Pérez 2008), although the size of most of the 50 populations and subpopulations have yet to be assessed adequately and even though its numbers and densities continue to increase (Acevedo and Cassinello 2009).

Two projects were drafted for the reintroduction of the species in the Pyrenees (Herrero et al. 2002, Crampe et al. 2012). These projects involved identifying potential suitable areas for the experimental release of the animals based on the characteristics of the areas where Iberian wild goat populations have persisted in recent years. The analysis of these experiences can be resumed largely due to the importance of identifying large areas that are suitable for Iberian wild goats in the Pyrenees and protected areas. Recently, some models have examined habitat suitability for the whole Peninsula (Acevedo and Real 2011).

Since the mid-1990s, observations of the Iberian wild goats (Capra pyrenaica hispanica) originally from 
the Sierra de Cazorla (Andalusia), which escaped from a fenced hunting enclosure, have been documented in Guara Nature Park in the Spanish Pre-Pyrenees (Ebronatura 1996, Herrero et al. 2006). The number of original founders (probably few) and the number that escaped from the enclosure are unknown.

In this paper, we document the status of the Guara Nature Park Iberian wild goat population, including its distribution, size, and structure. We also address some of the challenges to the conservation of Iberian wild goat in the Pyrenees as well as the prospects for re-colonization in the region.

\section{Materials and methods}

In four field sessions per year (April, June, October, and November-December), Iberian wild goats were counted from five fixed points with good visibility (Nievergelt 1981), using binoculars and spotting scopes. The sampling protocol was based on previous testimonies on the presence of the species. All of the surveys occurred for at least $3 \mathrm{~h}$ after dawn (2006-2012) and also in late afternoon (2006 and 2007), which were the periods when Iberian goats were most active (Escós and Alados 1988). With the assistance of the rangers of Guara Nature Park and other volunteers, we recorded the sex and age of the animals, with individuals assigned to one of the following age-sex classes: kids, 1- and 2-year-old yearlings, adult females, young males (3-6 years), middle age males ( $7-10$ years), and old males ( $>10$ years).

In 2007 a 1-year-old female Iberian wild goat was observed during a mammal tracks survey near Canciás Massif (CM) ( $42^{\circ} 27^{\prime} 5^{\prime \prime} \mathrm{N}$; $\left.0^{\circ} 7^{\prime} 21^{\prime \prime}\right), 10 \mathrm{~km}$ north of Guara Nature Park. Then, in the spring of 2008, two groups of Iberian wild goats were observed at CM during a survey of griffon vultures Gyps fulvus. For these reasons, beginning in the autumn of 2008, one fixed point and one set of simultaneous itinerary surveys were conducted in $\mathrm{CM}$ four times per year. When the same observations were obtained in a new area in Guara Nature Park (Balced), two new fix points were conducted there during 2011 and 2012. The locations of all of the groups were mapped using a geographic information system. The area occupied by the groups was estimated based on the minimum convex polygon method.

Changes in the annual number of Iberian wild goats as a function of time were analyzed using Poisson regression (Kleinbaum et al. 1988, Doménech and Navarro 2005), in which the dependent variable was a count that followed the Poisson distribution. We defined a generalized linear model fit with the GLM procedure of R (R Development Core Team 2012), with the response variable given by the annual count of Iberian wild goat, a Poisson error distribution, and a natural log link function for the exponential growth model, for which the parameter $\mathrm{b}$ can be interpreted as $r$ or the intrinsic rate of increase, and lambda $\lambda$ coming from the $r$ neperian antilog.

\section{Study area}

Guara Nature Park ( $42^{\circ} 16^{\prime} 38^{\prime \prime} \mathrm{N}$; $0^{\circ} 7^{\prime} 59^{\prime \prime}$ W) covers a 40-km-long S Pre-Pyrenean E-W mountain range of 81,494 ha, where the elevation ranges between $430 \mathrm{~m}$ and 2077 $\mathrm{m}$, which means that the landscape has a rough relief and steep slopes. Half of the surface consists of shrubs (Echinospartum horridum, Juniperus communis, Buxus sempervirens), one fourth consists of forest (mainly Quercus ilex, Pinus sylvestris, Pinus nigra, Quercus humilis, Pinus uncinata and Fagus sylvatica, in decreasing order of importance), and one-fourth is rock. Hunting is prohibited in about a quarter of the park, and the remainder comprises 48 hunting grounds that are managed by local hunters. Of these, one fenced hunting ground was where the wild goats escaped (Bastarás 42 $14^{\prime} 22,87^{\prime \prime} \mathrm{N} ; 0^{\circ} 8^{\prime} 17,70^{\prime \prime} \mathrm{W}$ ). The primary game animal is wild boar Sus scrofa and over 1000 are harvested each year. The Iberian wild goats co-exist with other wild ungulates (roe deer, Capreolus capreolus; red deer, Cervus elaphus) and several hundred feral goats C. hircus (Herrero et al. 2013). For additional information on the study area, see Herrero et al. (2006) and Paula et al. (2006) for the area's long-term monitoring ecological plan.

\section{Results}

Iberian wild goats occupied the Guara Nature Park and $\mathrm{CM}$ in the Spanish Pyrenees (Figure 1). The demographics of the population are presented in Table 1 . The sex ratio of the population was biased towards males, annual productivity was variable, and the area occupied by the population had increased (Table 1 and Figure 1). In both massifs, Iberian wild goats were sympatric with feral goats, but permanent mixed groups did not occur. The population showed a positive increasing trend $(\lambda=1.067 ; \mathrm{CI}=95 \%$ : 1.015 to $1.12 ; \mathrm{p}<0.001$ ).

\section{Discussion and conclusions}

The population of Iberian wild goat in Guara Nature Park appeared to have a reproductive rate and population 


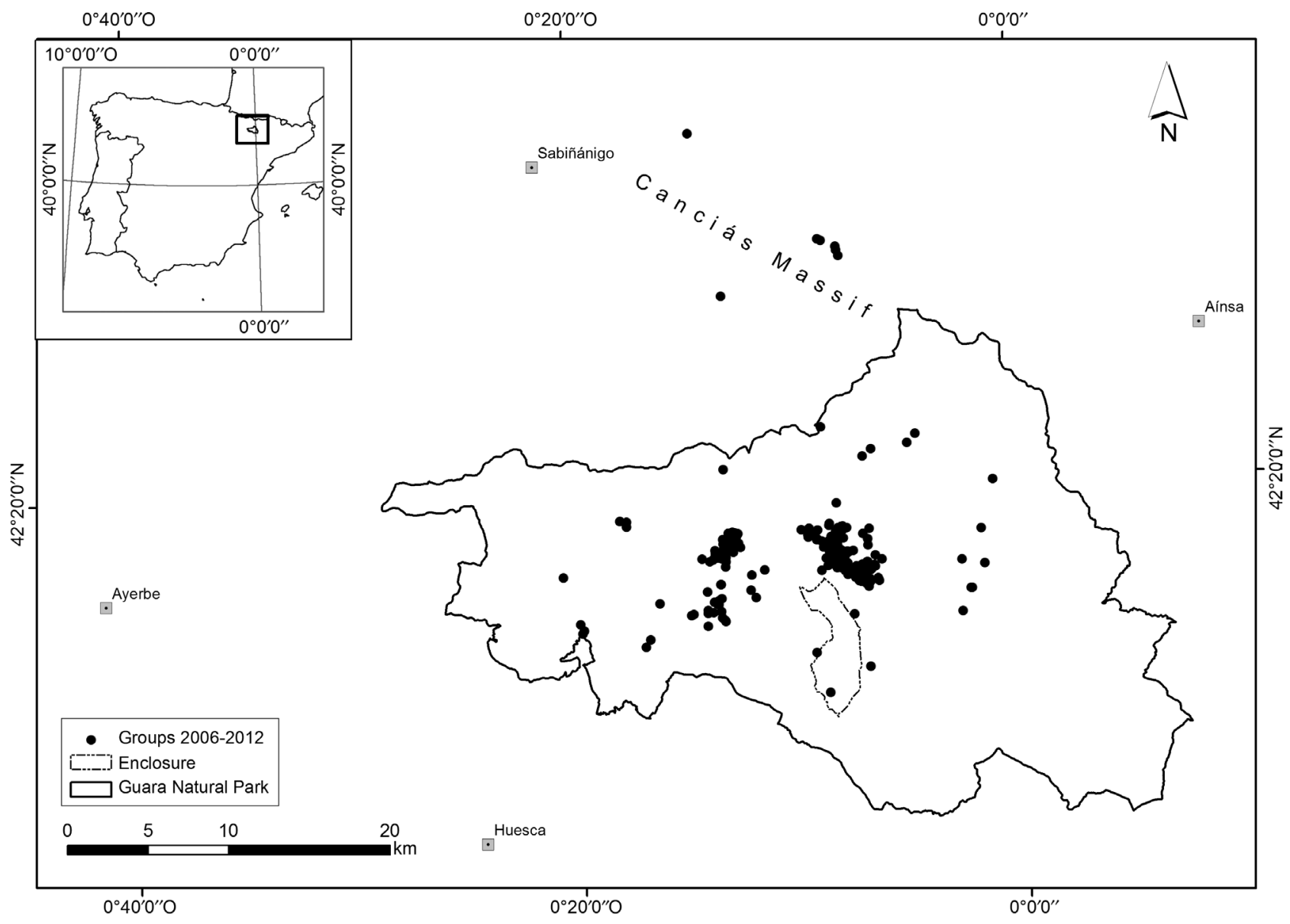

Figure 1 Presence of Iberian wild goat in Guara Nature Park in the Spanish Pyrenees between 2006 and 2012.

structure, which were within the range of the rest of populations (Alados and Escós 2003), and slowly expanded into neighboring areas.

The Iberian wild goat population in Guara Nature Park was isolated from others (Marco et al. 2011). Populations founded by a small number of individuals and,

Table 1 Iberian wild goat population structure in Guara Nature Park (2006-2012).

\begin{tabular}{lrrrrrrr}
\hline & $\mathbf{2 0 0 6}$ & $\mathbf{2 0 0 7}$ & $\mathbf{2 0 0 8}$ & $\mathbf{2 0 0 9}$ & $\mathbf{2 0 1 0}$ & $\mathbf{2 0 1 1}$ & $\mathbf{2 0 1 2}$ \\
\hline Adult males & 14 & 25 & $27+1$ & $24+1$ & 17 & 31 & 35 \\
Adult females & 22 & 17 & $15+1$ & 13 & 12 & $21+1$ & 35 \\
Yearlings & 6 & 1 & $4+1$ & 6 & 2 & 10 & 9 \\
Kids & 15 & 8 & 7 & 4 & 6 & 6 & 7 \\
Total & $\mathbf{5 7}$ & $\mathbf{5 1}$ & $\mathbf{5 3 + 3}$ & $\mathbf{4 7 + 1}$ & $\mathbf{3 7}$ & $\mathbf{6 8 + 1}$ & $\mathbf{8 6}$ \\
Sex ratio M/F & 0.64 & 1.47 & 1.80 & 1.85 & 1.42 & 1.48 & 1 \\
Productivity & 68 & 47 & 47 & 31 & 50 & 29 & 20 \\
MCP $\left(\mathrm{km}^{2}\right)$ & 35 & 79 & 176 & 231 & 191 & 380 & 169 \\
\hline
\end{tabular}

${ }^{1}$ Animals seen in Canciás Massif. MCP, Minimum convex polygon. therefore, probably with low genetic diversity, can face greater challenges than those with high genetic diversity (e.g., Moço et al. 2006, Granados et al. 2007). For instance, differences in the amount of genetic diversity might be one of the reasons why the species is sensitive to mange Sarcoptes scaibiei, which is a disease that threatens the species in different parts of its range (León-Vizcaino et al. 1999). The translocation of animals with high genetic diversity from nearby large populations should be a priority for the management of this population at this stage of the re-colonization, that is, when the release of new individuals can dramatically increase the genetic variability of the population (Frankham 2005).

The role of enclosures and the animals that escape from them both represent the origin of the Portuguese (Moço et al. 2006) and Pyrenean populations of Iberian wild goat. These unintended re-introductions pose the same conservation problems associated with low genetic variability, which compromise the viability of these populations. The IUCN (2012) recommended that 
re-introductions should include the pre- and post-release control and monitoring of the individuals released.

Feral goats comprised the most important population of the Capra species in the area, and there were about 700 individuals in Guara Nature Park in 1995 (Gortázar et al. 1997). In 2009, the park had 941 individuals, with another 10 in CM (García-Serrano et al. 2009, Herrero et al. 2013). No competence interactions were observed between both species, in spite of what had been proposed in Southern Iberia for kept domestic goats and Iberian wild goats (Acevedo et al. 2007). Habitat overlap was clear and food habits were also highly overlapped, with feral goats using trophic resources more like Iberian wild goats than domestic goats (Aldezabal and Garin 2000). The overall sanitary status of the feral goats was healthy, and no particular pathology affected this population (Gortázar et al. 1997).

Some Capra species hybridize in the wild. Alpine ibex C. ibex and feral goats hybridize to an exceptional degree, but it is not a conservation concern (Giacometti et al. 2004). Although the popular view is that hybrids exist in several areas within its distribution range (J. Pérez, D. Fernández de Luco, J. Granados, P. Fandos and J.-P. Crampe, pers. comm.), there is no scientific evidence that feral goats and Iberian wild goats hybridize in the wild (Granados et al. 1997, 2007, 2008, Pérez et al. 2002, Alados and Escós 2003, Herrero and Pérez 2008, Acevedo et al. 2009). Hybrids have occurred in captivity (Fernández-Arias et al. 1999, Alasaad et al. 2012), through in-vitro fertilization (Fernández-Arias et al. 2001) and natural copulation after a long period of cohabitation between male Iberian wild goats and domestic female goats (Fernández-Arias pers. com.). Moreover, it seems that some physiological reproductive incompatibility between both domestic and wild goat could exist (Fernández-Arias et al. 1999). This could explain why those species have coexisted for several millennia on the Iberian Peninsula, without affecting the genetic identity of the Iberian wild goat. Differences in behavior might also limit or prevent inter-breeding but. Nevertheless, the coexistence of a small population of Iberian wild goat and a large population of feral goats is a situation that should be monitored closely. The existence of this population, which originated from an unintentional escape, does not follow IUCN standards for re-introductions (2012), and belongs to a population that is genetically distant from the extinct Pyrenean wild goat (Manceau et al. 1999). Thus, monitoring should continue, along with the study of this population's interactions with feral domestic goats; furthermore, its future must be decided as soon as possible, considering eradication or restocking (Pérez et al. 2012).

Acknowledgements: This research was financed by the Government of Aragon, through the Ecological Monitoring Program of Guara Nature Park. For their dedication, we thank the park rangers, technicians, and other volunteers who contributed to the field work.

Received January 18, 2012; accepted April 9, 2013; previously published online May 3, 2013

\section{References}

Acevedo, P. and J. Cassinello. 2009. Biology, ecology and status of the Iberian ibex Capra pyrenaica: A critical review and research prospectus. Mamm. Rev. 39: 17-32.

Acevedo, P. and R. Real. 2011. Biogeographical differences between the two Capra pyrenaica subspecies, C.p.victorieae and C.p.hispanica, inhabiting the Iberian Peninsula: Implications for conservation. Ecol. Model. 222: 814-823.

Acevedo, P., J. Cassinello and G. Gortázar. 2007. The Iberian ibex is under an expansion trend but displaced to suboptimal habitats by the presence of extensive goat livestock in central Spain. Biodiv. Conserv. 16: 3361-3376.

Alados, C.L. and J. Escós. 2003. Cabra montés - Capra pyrenaica Schinz, 1838. In: (L.M. Carrascal and A. Salvador, eds.) Enciclopedia Virtual de los Vertebrados Españoles [Internet]. Museo Nacional de Ciencias Naturales, Madrid. Available from: http://www.vertebradosibericos.org/. Accessed on 21 January 2012.

Alasaad, S., J. Fickel, L. Rossi, M. Sarasa, C.V. Benitez, J.E. Granados and R.C. Soriguer. 2012. Applicability of major histocompatibility complex DRB1 alleles as markers to detect vertebrate hybridization: a case study from Iberian ibex $x$ domestic goat in Southern Spain. Acta Vet. Scan. 54:56: 1-6.

Aldezabal, A. and I. Garin. 2000. Browsing preference of feral goats (Capra hircus L.) in a Mediterranean mountain scrubland J. Arid Environ. 44: 133-142.

Astre, G. 1952. Quelques étapes de la disparition du bouquetin aux Pyrénées centrales. Rev. Comminges 65: 129-146.

Crampe, J.-P., E. Sourp, L. Rieu and P. Lapenu. 2012. Réintroduction du bouquetin Ibérique dans le Parc National des Pyrénées. Report of the Parc National des Pyrénées. http://www. parc-pyrenees.com/diffusion-des-donnees/cat_view/103etudes-scientifiques/130-faune.html. Accessed on January 2013.

Doménech, J.M. and J.B. Navarro. 2005. Regresión logística binaria, multinomial y de Poisson. Signo, Barcelona, Spain.

Ebronatura. 1996. Research on the current situation of feral goats Capra hircus in Guara Nature Park. Internal report of the Government of Aragon, Spain.

Escós, J. and C.L. Alados. 1988. Estimating mountain ungulate density in Sierras de Cazorla y Segura. Mammalia 52: 425-428. 
Fernández-Arias, A., J.L. Alabart, J. Folch and J.F. Beckers. 1999. Interspecies pregnancy of Spanish ibex (Capra pyrenaica) fetus in domestic goat (Capra hircus) recipients induces abnormally high plasmatic levels of pregnancy-associated glycoprotein. Theriogenology 51: 1419-1430.

Fernández-Arias, A., A. Roche, R. Alberio, J.L. Alabart and J. Folch. 2001. Use of hybrids as recipients in interspecies embryo transfer in the Capra genus. J. Theriogenology 55: 383.

Fernández de Luco, D., J.M. Seijas, R. García-González, M. Gonzalo, M. Fernández, J.G. Fernández, H.C. Serodio, D. Ferreira, M.C. Arnal, J. Herrero and J.L. Clavero. 2000. The last bucardo (Capra pyrenaica pyrenaica) in the Pyrenees died from politraumatism after being squashed under a falling fir (Abies alba). Fourth European Wildlife Disease Association. Zaragoza, 20-23 September, 2000.

Frankham, R. 2005. Genetics and extinction. Biol. Conserv. 126: 131-140.

García-González, R. and J. Herrero. 1999. The extinction of the Pyrenean wild goat. Galemys 11: 17-26.

García-González, R., J. Escós and C.L. Alados. 1996. Una población en peligro: el bucardo. In: (C.L. Alados and J. Escós, eds.) Ecología y comportamiento de la cabra montés. Consideraciones para su gestión. Monografías del Museo de Ciencias Naturales, CSIC, Madrid. pp. 105-120.

García-Serrano, A., O. Fernández-Arberas, C. Prada and J. Herrero. 2009. Feral goat Capra hircus population estimation in Guara Nature Park. Unpublished report of the Government of Aragon, Spain.

Giacometti, M., R. Roganti, D. De Tann, N. Stahlberger-Saitbekova and G. Obexer-Ruff. 2004. Alpine ibex Capra ibex ibex $\mathrm{x}$ domestic goat $C$. aegagrus domestica hybrids in a restricted area of southern Switzerland. Wildl. Biol. 10: 137-143.

Gortázar, C., J. Ferreres, J. Marco, D. Fernandez de Luco, I. Garin and A. Aldezabal. 1997. The feral goat in Guara (Aragón, Spain): conservation or eradication. Bulletin d'information sur la pathologie des animaux sauvages en France (BIPAS) 17: 73-79.

Granados, J.E., M. Chirosa, M.C. Pérez, J. Pérez, I.R. Ruíz-Martínez, R.C. Soriguer and P. Fandos. 1997. Distribution and status of the Spanish ibex Capra pyrenaica in Andalusia, Southern Spain. Proc 2nd World Conference Mt Ungulates; St. Vincent (Aosta), Italia 1997.

Granados, J.E., R.C. Soriguer, J.M. Pérez, P. Fandos and J.G. García-Santiago. 2007. Capra pyrenaica Schinz 1838. In: (J. Palomo, J. Gisbert and J.C. Blanco, eds.) Atlas y libro rojo de los Mamíferos terrestres de España. Dirección General de la Naturaleza, SECEM, SECEMU, Madrid. pp. 366-368.

Granados, J.E., J. Cano-Manuel León, P. Fandos París and R. Cadenas del Llano Aguilar. 2008. Conclusions. In: (J.E. Granados, J. Cano-Manuel León, P. Fandos, R. Cadenas del Llano, eds.) Trends in the study and conservation of Caprinae in Europe. Environmental Ministry of the Andalusian Regional Government, Granada, Spain. pp. 319-320.

Herrero, J. and J.M. Pérez. 2008. Capra pyrenaica. In: IUCN 2009. IUCN Red List of Threatened Species. Version 2009.2. Available from: http://www.iucnredlist.org. Accessed on 01 January 2012.
Herrero, J., C. Prada and A. García-Serrano. 2002. Draft for a re-introduction plan of Iberian wild goat Capra pyrenaica in the Pyrenees. Unpublished report of the Government of Aragon, Spain.

Herrero, J., C. Prada, A. García-Serrano and O. Fernández Arberas. 2006. Mammals of Guara. Publicaciones del Consejo de Protección de la Naturaleza de Aragón, Spain.

Herrero, J., O. Fernández-Arberas, C. Prada and A. García-Serrano. 2013. Size and density of a feral goat Capra hircus population in Guara Nature Park, Pyrenees. Wildl. Biol. Pract. (in press).

IUCN. 2012. IUCN Guidelines for Reintroductions and Other Conservation Translocations. Adopted by SSC Steering Committee at Meeting SC 4 6, 5th September 2012.

Kleinbaum, D.G., K.L. Lawrence and M.E. Keith. 1988. Applied regression analysis and other multivariable methods. 2nd edition. The Duxbury Series in Statistics and Decision Sciences. PWS-KENT Publishing Co., Boston, Massachusetts, USA.

León-Vizcaino, L., M.R. Ruíz de Ibañez, M.J. Cubero, J.M. Ortíz, J. Espinosa, L. Pérez, M.A. Simón and F. Alonso. 1999. Sarcoptic mange in Spanish ibex from Spain. J. Wildl. Dis. 35: 647-659.

Manceau, V., J.P. Crampe, P. Boursot and P. Taberlet. 1999. Identification of evolutionary significant units in the Spanish wild goat, Capra pyrenaica (Mammalia, Artiodactyla). Animal Conservation 2: 33-39.

Marco, J., J. Herrero, M.A. Escudero, O. Fernández-Arberas, J. Ferreres, A. García-Serrano, A. Giménez-Anaya, J.L. Labarta, L. Monrabal and C. Prada. 2011. Veinte años de seguimiento poblacional de ungulados silvestres de Aragón. Pirineos, A Journal on Mountain Ecology 166: 135-153.

Moço, G., M. Guerreiro, A.F. Ferreira, A. Rebelo, A. Loureiro, F. Petrucci-Fonseca and J.M. Pérez. 2006. The ibex Capra pyrenaica returns to its former Portuguese range. Oryx 40 : 351-354.

Nievergelt, B. 1981. Ibexes in an African Environment. SpringerVerlag, Berlin. pp. 189.

Paula, A., C. Prada, J. Herrero, A. García-Serrano and J.A. Atauri. 2006. Ecological monitoring in Guara Nature Park. Natur. Aragon. 17: 56-64.

Pérez, I., J.A. Anadón, M. Díaz, G.G. Nicola, J.L. Tella and A. Giménez. 2012. What is wrong with current translocations? A review and a decision making proposal. Front. Evol. Envion. doi:10.1890/110175

Pérez, J.M., J.E. Granados, R.C. Soriguer, P. Fandos, F.J. Márquez and J.-P. Crampe. 2002. Distribution, status and conservation problems of the Spanish ibex, Capra pyrenaica (Mammalia: Artiodactyla). Mamm. Rev. 32: 26-39.

Pidancier, N., S. Jordan, G. Luikart and P. Taberlet. 2006. Evolutionary history of the genus Capra (Mammalia, Artiodactyla): discordance between mitochondrial DNA and Y-chromosome phylogenies. Mol. Phylogenet. Evol. 40(3): 739-749.

R Development Core Team. 2012. R: A language and environment for statistical computing. R Foundation for Statistical Computing, Vienna, Austria. ISBN 3-900051-07-0, URL http://www.Rproject.org/.

Schaller, G.B. 1977. Mountain Monarchs: wild sheep and goats of the Himalaya. University of Chicago Press, Chicago. 